Dr. Hoare has taken an active part in the administration of the University; he represented the Faculty of Science on the Court from 1950 until 1952, held office as Dean of the Faculty of Science from 1958 until 1961, and has served as an additional member of the Senate for the periods 1960-62 and 1964-65. $\mathrm{He}$ is a member of the Council's Advisory Committees on the Education and Training of Non-academic Staff and on the Welfare of Clerical, Technical and Maintenance Staffs. During his time at Leeds he has initiated investigations at very low temperatures and has built up the facilities for this work with particular reference to the properties of metals and alloys. He has published many papers on the thermal and magnetic properties of the transition elements and is the author of an undergraduate text-book on thermodynamics as well as part author and co-editor of a reference book on low-temperature techniques.

\section{Development of Nuclear Power in Britain}

IN a written answer in the House of Commons on December I, the Minister of Power, Mr. F. Lee, said that the Governmont proposed to keep the further development of the British Nuclear Power programme under review as envisaged in the White Paper on the Second Nuclear Power Programme. The question of the type of reactor to be included would be considered when the results of the enquiry for tenders for the first station in the programme were available in 1965 . In reply to a further question on December 8, Mr. Lee offered no further information, but the position of the electricity, gas and nuclear energy industries generally was raised in the House of Lords on December 8. Lord Hawke pointed out that capital costs had been coming down and were now about $£ 40$ per $\mathrm{kW}$ for conventional stations.

In reply for the Government, Lord Stonham said that the Government fully recognized that Britain's economy and planned expansion were dependent on the production of power and that the fulfilment of a policy to meet that domand efficiently and economically required investment on a massive and increasing scale. In 1963 the gas industry in Great Britain spent more than $£ 90$ million on capital account, and the nationalized electricity industry in England and Wales, including nuclear power stations, spent almost $£ 490$ million. The annual capital expenditure in the electricity industry was expected to increase substantially, and a figure of $£ 673$ million had been approved for the next financial year. Capital investment by the Gas Boards was not expected to be more than about $£ 100$ million a year, but it was impossible to give precise forecasts until the Government's present review of public expenditure and investment had been completed. It was certain, however, that the $\$ 770$ million expected to be invested over the next year in gas and electricity would bo insufficient if in the years ahead the growth of the economy were to be supported and domestic requirements mot. The Generating Board's proposals should give a reserve margin of plant by about 1970 of some 17 per cent, and this would involve investment totalling $£ 4,000$ million over the next six years. Lord Stonham went on to point out that nuclear plants would play an increasingly important part, but the present nine stations were of the magnox type; the tenders which had been invited for the advanced gas-cooled reactor type could not be expected until well into the summer of $\mathbf{1 9 6 5}$. Little hope could be held out for great expansion in regard to pump storage, although pump storage stations had a longer working life than conventional generating plants. Further advances in the technology of conventional generation might, however, make pump storage schemes more attractive, as would the growing availability of nuclear power when the capacity of nuclear power plants was sufficient to supply the minimum load on the system and surplus lowcost nuclear energy was available for night pumping. Lord Sherfield thought that the target of 5,000 MW of additional nuclear power by 1975 was on the low side, although he agreed that there were difficult questions of priorities and national interest. He urged the importance of firm decisions, while Earl Ferris referred to the neces. sity of spending much more money on research into the possibility of laying underground cables more cheaply and more effectively, as was being done in other countries.

\section{Future of Teacher Training Colleges in England and Wales}

IN a statement in the House of Commons on December 11, the Secretary of State for Education and Science, Mr. M. Stewart, said the Government had now considered the recommendations of the Robbins Committee on the future of the teacher training colleges in England and Wales. The Government agreed that wider opportunities should be given to suitable teacher training college students to take a degree together with a professional teaching qualification by means of a four-year course. However, after considering the advice given by the University Grants Committee, the Government had concluded that the academic and administrative and financial aspects were separable and that fundamental changes should not, at the present time, be made in the administrative and financial structure of the teachers training system. It had therefore been decided that the colleges should continue to be administered by the existing maintaining body under the present system of overall supervision, but the present arrangements for the internal government of colleges would be reviewed forthwith by all those concerned, in the light of the recommendations of the Robbins Committee. It had been agreed that the training colleges could appropriately be renamed 'Colleges of Education'. Mr. Stewart believed that the colleges should have a proper measure of independence in academic matters, and he thought that it was particularly important that local authoritios should attend to this.

\section{Overseas Development}

IN reply to questions in the House of Commons on December 15, the Minister of Overseas Development, Mrs. B. Castle, said that about 550 in the direct employment of her Department, including specialized project advisers, were expected to be serving overseas in 1965; some 140 could be attributed to functions of the Department of Technical Co-operation. The Commonwealth Development Corporation was being transferred to her Department, and when this was completed she would review the functions and resources of the Corporation in the light of the needs of the British aid programme as a whole. Arrangements already existed for the co-ordination of educational assistance under technical co-operation arrangements and through the British Council, and this co-ordination would be strengthened. The annual rate of appointment of qualified technical staff for Commonwealth Africa had been more than doubled since 1962 and a thorough review of recruitment policy generally had been commenced. Total assistance from Britain to the less-developed countries in 1963 was estimated at $£ 227 \cdot 8$ $£ 247.8$ million compared with $£ 273.9$ million in 1961 and $£ 218.3$ million in 1962. Of the 1963 figure, bilateral economic aid was $\$ 138.9$ million and private investment $£ 70-90$ million.

\section{Joint Study of Natural Gas Pipeline across the North Sea}

Sir Henry Jones, chairman of the Gas Council, stated in London on November 30: "The Gas Council and N.V. Nederlandse Aardolie Maatschappij (Gas Export) have agreed to initiate a joint study of the technical and economic aspects of a natural gas pipeline from the Netherlands to Great Britain across the North Sea. The study will enable work which has hitherto been performed separately to be continued in more detail. It does not indicate any commitment by either party to supply or to take gas at any future date". 